\title{
Isolation of Stem Cells from Pulp Deciduous Teeth Dog
}

\author{
Jaime Sarda Aramburu ${ }^{1 *}$, Tiago Luis Eilers Treichel $^{1}$, Saulo Tadeu Lemos Pinto Filho ${ }^{1}$, \\ Matheus Pippi da Rosa ${ }^{1}$, Sergio Alexandre Gehrke ${ }^{2}$ and Ney Luis Pippi ${ }^{1}$ \\ ${ }^{1}$ Laboratory of Cell Therapy, UFSM, Santa Maria, Rio Grande do Sul, Brazil \\ ${ }^{2}$ Cellular and Molecular Biology, Biotecnos, Santa Maria, Rio Grande do Sul, Brazil
}

Received: October 02, 2014; Accepted: October 15, 2014; Published: October 29, 2014

*Corresponding author: Jaime Sarda Aramburu, Laboratory of Cell Therapy, UFSM, Santa Maria, Rio Grande do Sul, Brazil, Tel: +55-559-901-3740;

E-mail: jaimearamburujunior@gmail.com

\begin{abstract}
Stem Cells (SC) have the potential for self-renewal and differentiation. And some research groups used cell therapy to regenerate lost or injured tissues. With that some research groups to use in cell therapy to regenerate lost or injured tissues. The isolation of SC can be performed in various tissue origins. This paper aims to describe a protocol for isolation of stem cells from the pulp of deciduous teeth dog.
\end{abstract}

Keywords: Deciduous tooth; Deciduous tooth pulp stem cells; Dogs

\section{Introduction}

The Stem Cells (SC) are defined as cells capable of selfrenewal and tissue differentiation. They are present in all tissues $[1,2]$ and can be obtained from endodermal, mesodermal and ectodermal tissues [3]. Stem cells have been isolated from: bone marrow, neural tissue, skin, retina and human dental pulp [1,4].

The Stem Cells (SC) are classified according to origin in embryonic/fetal or adult/postnatal. The difference between them is in plasticity, or the potential to produce different specialized cell lines. Since embryonic have great plasticity, but their use is still surrounded by ethical and legal issues [1].

Early studies with human SC were made with pulp tissue of extracted third molars [5] teeth. The discovery of SC dental pulp and the advancement of cellular and molecular biology led to the development of new regenerative therapies [6]. The pulp stem cells from permanent or deciduous teeth are able to provide cells for clinical application [5]. In dentistry, tissue engineering explores the SC primary or permanent teeth [7].

The possibility of using stem cells to regenerate the periodontium has motivated researchers [8] because periodontal regeneration represents a major breakthrough in periodontal therapy [9].

As Lin et al. [8], cells in bone marrow and adipose tissue regenerate alveolar bone and form a structure similar to the periodontal ligament. Tissue engineering has been aided by animal studies showing positive results [10].

\section{Material and Methods}

This study was previously submitted to the appreciation of Ethics Committee on Animal Use (CEUA) of UFSM having been approved and received the approval number: 084/2011. To this, five canines persistent deciduous teeth of dogs (Figure 1) derived from the routine of the Veterinary Teaching Hospital (HVU) UFSM were used. Each tooth after extraction was immersed in a $50 \mathrm{ml}$ polypropylene tube with $10 \mathrm{ml}$ of Hank's solution (SigmaAldrich) at room temperature for transport to the laboratory. The procedure for obtaining dental pulp was carried out in the UFSM Cellular Therapy Laboratory aseptically with the materials sterilized by autoclaving and Ultra-Violet (UV) radiation. Inside the laminar flow hood, the container containing the tooth was opened and, with forceps dissection, the tooth was transferred to a Petri dish. This tooth plate was washed 3 times with Hank's solution using a $10 \mathrm{ml}$ syringe. After this process, the tooth was grasped with forceps needle holder in the crown region and with the aid of a rongeur, the pulp chamber was accessed by the root apex. The Pulp Tissue (PT) was removed from the interior of the tooth with the aid of an endodontic file. Further, the PT was chopped and placed in a polypropylene tube type of solution with $0.2 \%$ collagenase type I (Sigma-Aldrich) in a water bath at $37^{\circ} \mathrm{C}$ for 60 minutes. The cell suspension was centrifuged at $800 \mathrm{~g}$

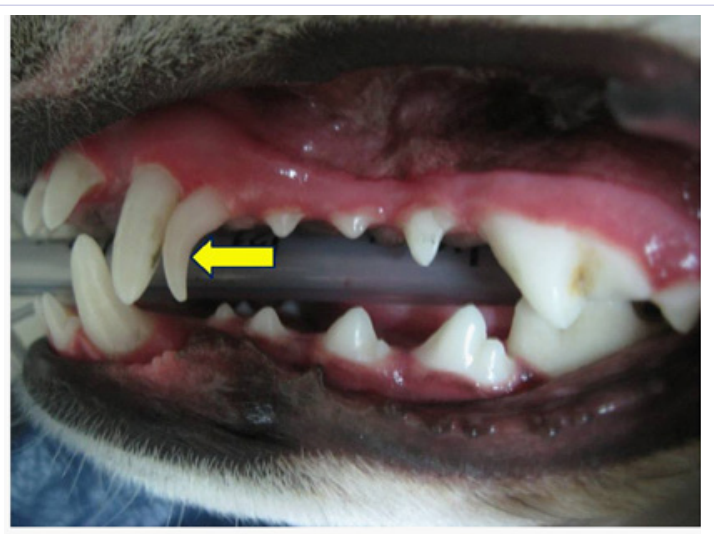

Figure 1: Deciduous tooth from which the pulp was obtained for cell culture. 
for 5 minutes at room temperature. The pellet was re suspended in DEMEM/HEPES (Gibco) culture medium, supplemented with $10 \%$ fetal bovine serum (Gibco), 100 units/ml penicillin, $100 \mu \mathrm{g} /$ $\mathrm{ml}$ streptomycin (Gibco) and $3.7 \mathrm{mg} / \mathrm{L}$ HEPES (Sigma-Aldrich). Centrifuged again at $800 \mathrm{~g}$ for 5 minutes, while the medium was discarded and the resulting cell suspension was seeded into one well of a 6 well plate. The exchange of culture medium was after 24 hours of the initial plating and after every 2-3 days. The culture was maintained under these conditions until greater than $80 \%$ confluence (Figure 2), when it held its first passage confluence. In transplants, the cells in culture were harvested with a solution of $0.5 \%$ trypsin-EDTA (Sigma-Aldrich) and transferred to subcultures in the respective culture medium. The subculture was maintained in monolayer until its next peal was necessary. Cultures of stem cells were transplanted up to 8 times.

\section{Results and Discussion}

Isolation and culture of pulp tissue was considered positive, since $80 \%$ of the samples showed cell growth after 24 hours of cultivation. Luisi et al. [11] observed a similar result.

The methodology for storage and transport of biological material from the time it was collected until processing differs from Bernardi et al. [12], but proved to be efficient regarding contamination, since none of the cell cultures was affected. It is believed that the prior training of the team was determinant to the result.

Access to dental pulp was safe and effective only with the use of alveolotomo while Bernardi [13] made use of high rotation and drills, which is not always present in lab equipment. Unlike Miura et al. [14] who added to this dispase solution. With this, protocol becomes more practical, less expensive and is also financially efficient for cell proliferation.

In considering the description of Peng et al. [8] about the easy and rapid expansion of stem cells from the dental pulp of human deciduous tooth in vitro, we can mention that the dental pulp of deciduous teeth of dogs had similar behavior, because it got the proper confluence mobile ringing in the shortest time quoted in the literature [11].

Meeting isolation and cell culture are requirements to work

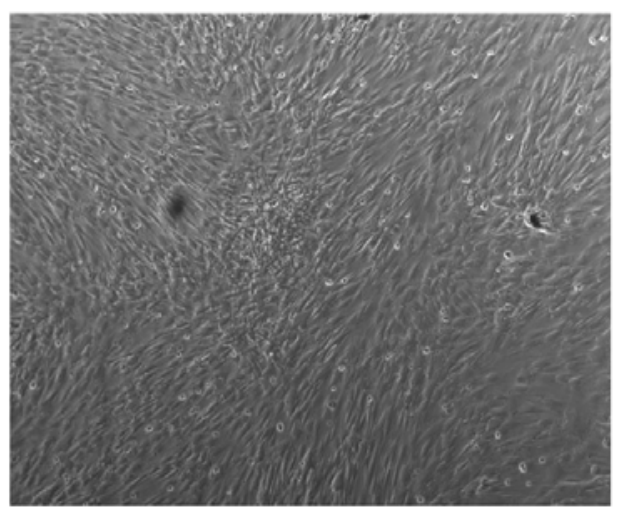

Figure 2: More than $90 \%$ of the culture plate, suitable for performing cell confluence passage time. with regeneration of tissue when using cell therapy [8]. The protocol suggested in this paper can help new groups that have an interest in this research line.

\section{Conclusion}

The protocol suggested by our group is efficient for the isolation of dental pulp of deciduous teeth of dogs and features a lower financial cost if the methodology used by other research groups to obtain stem cells were purchased.

\section{Acknowledgments}

The authors are grateful to National Counsel of Technological and Scientific Development (CNPq, Brazil).

\section{References}

1. Casagrande L. Aplicação de princípios de engenharia tecidual no estudo da diferenciação de células-tronco pulpares. 61f. Tese (Doutorado em Clínica Odontológica) - Universidade Federal do Rio Grande do Sul, Porto Alegre, 2008.

2. Ulmer FL, Winkel A, Kohorst P, Stiesch M. Stem cells - prospects in dentistry. Schweiz Monatsschr Zahnmed. 2010; 120(10): 860-72.

3. Fortier LA. Stem cells: classifications, controversies, and clinical applications. Vet Surg. 2005; 34(5): 415-23.

4. Gronthos S, Brahim J, Li W, Fisher LW, Cherman N, Boyde A. et al. Stem cell properties of human dental pulp stem cells. J Dent Res. 2002; 81(8): 531-35.

5. Lin NH, Gronthos S, Bartold PM. Stem cells and future periodontal regeneration. Periodontol. 2000. 2009; 51: 239-51. doi: 10.1111/j.16000757.2009.00303.x

6. Casagrande L, Cordeiro MM, Nör SA, Nör JE. Dental pulp stem cells in regenerative dentistry. Odontology. 2011; 99(1): 1-7. doi: 10.1007/s10266010-0154-z.

7. Koyama N, Okubo Y, Nakao K, Bessho K. Evaluation of pluripotency in human dental pulp cells. J Oral Maxillofac Surg. 2009; 67(3):501-6. doi: 10.1016/j.joms.2008.09.011.

8. Peng L, YE L, Zhou XD. Mesenchymal stem cells and tooth engineering. Int J Oral Sci. 2009; 1(1): 6-12. doi: 10.4248/ijos.08032.

9. Yen AH, Yelick PC. Dental tissue regeneration - a mini-review. Gerontology. 2011; 57(1): 85-94. doi: 10.1159/000314530.

10. Ivanovski S, Gronthos S, Shi S, Bartold PM. Stem cells in the periodontal ligament. Oral Dis. 2006; 12(4): 358-63.

11. Luisi SB, Barbachan JJ, Chies JA, Filho MS. Behavior of human dental pulp cells exposed to transforming growth factor-betal and acidic fibroblast growth factor in culture. J Endod. 2007, 33: 833-35.

12. Bernardi L, Luisi SB, Fernandes R, Dalberto TP, Valentim L, Bogo Chies JA. et al. The isolations of stem cells from human deciduous teeth pulp is related to the physiological process of resorption. J Endod. 2011; 37(7): 973-9. doi: 10.1016/j.joen.2011.04.010.

13. Bernardi, L. Células-tronco da polpa de dentes decíduos humanos isolamento relacionado à rizólise dentária. 87f. Dissertação (Mestrado em Clínica Odontológica) - Universidade Federal do Rio Grande do Sul, Porto Alegre, 2009.

14. Miura M, Gronthos S, Zhao M, Lu B, Fisher LW, Robey PG, et al. SHED: stem cells from human exfoliated deciduous teeth. Proc Natl Acad Sci U S A. 2003 ; 100: 5807-12. 